\title{
PREPARING THE POSTCOLONIAL SITUATION: POLISH DRUGI OBIEG PERIODICALS, THE EUROPE TOPIC AND THE QUESTION OF POLAND'S EASTERN NEIGHBORS
}

\author{
RÜDIGER RITTER ${ }^{1}$ \\ (Universität Bremen)
}

Słowa kluczowe: czasopisma, drugi obieg, socjalizm, lata '80

Key words: journals, second circulation, socialism, 1980s

\begin{abstract}
Abstrakt: Rüdiger Ritter, PREPARING THE POSTCOLONIAL SITUATION: POLISH DRUGI OBIEG PERIODICALS, THE EUROPE TOPIC AND THE QUESTION OF POLAND'S EASTERN NEIGHBORS. „PORÓWNANIA” 13, 2013, t. XIII, s. 61-79. ISSN 1733-165X. Artykuł opisuje historię drugoobiegowych polskich czasopism sprzed 1989 roku. Analizuje warunki, w których te czasopisma musiały funkcjonować: funkcjonowanie w konspiracji, nieregularnie ukazujące się numery, niestabilność redakcji. Wśród głównych tematów autor podkreśla międzynarodowe ambicje polskich autorów. Mieli oni ambicje śledzenia przemian, zachodzących we wszystkich państwach komunistycznego obozu. Pragnęli także modernizować społeczeństwo, dzięki szerokiemu otwarciu łamów na teksty autorów zachodnich: filozofów, politologów, historyków, zwłaszcza tych, którzy zajmowali się fenomenem komunizmu.
\end{abstract}

\begin{abstract}
Rüdiger Ritter, PREPARING THE POSTCOLONIAL SITUATION: POLISH DRUGI OBIEG PERIODICALS, THE EUROPE TOPIC AND THE QUESTION OF POLAND'S EASTERN NEIGHBORS. „PORÓWNANIA” 13, 2013, Vol. XIII, p. 61-79. ISSN 1733-165X. The article describes the history of the Polish underground press (referred to as second circulation) before 1989. It offers an analysis of the conditions in which the magazines appeared including conspiracy, irregular printing and instability of the editorship. The author emphasises that the Polish writers aimed at going international. They observed the changes that took place in all the countries of the communist bloc. They also wanted to modernise the society by means of introducing texts by Western authors: philosophers, politologists, historians, especially those who dealt with the phenomenon of communism.
\end{abstract}

\footnotetext{
${ }^{1}$ Correspondence Address: RRitter@gmx.de
} 


\section{POSTCOLONIAL STUDIES AND OPPOSITIONAL JOURNALS}

Opposition movements in all state socialist countries were divided into a variety of groups with different political standpoints, from the extreme right wing to leftist orientations. But one idea was shared by nearly all these groups: it was the idea of being oppressed by the Soviet Union. The opposition in these states regarded their governments as instruments of the political centre in Moscow. Very early, i.e. in the 1960s if not earlier, oppositional thinkers in theses states used the terminology of colonialism for the description of their situation. State socialist countries were regarded as colonies of the Soviet Union. The task here is not to justify this idea. However, the very existence of a colonial thinking in these countries demonstrates the usefulness of applying the model of postcolonial studies to these countries as a model to describe their situation after 1989, after the breakdown of the state socialist system ${ }^{2}$. Postcolonial studies examine the shifting processes of thinking after the end of the colonial situation. The colonial consciousness, which had meant a strong orientation on the colonizer, begins to change into a post-colonial one, where this orientation is questioned and finally denied in order to establish one's own perspective ${ }^{3}$.

In the state-socialist countries, these processes of de-colonization or of preparing post-colonialism started already before the definite end of the colonizing system. The best example is Poland where the legalization of Solidarność stood at the beginning of a process leading finally to the destruction of the old political order. The idea of this article is to present Polish oppositional journals, magazines and periodicals as one important means to prepare for post-colonialism.

At the beginning of the 1980s in the Polish drugi obieg there appeared for the first time periodicals that aimed at being a marketplace for discourses on foreign policy issues. That was innovative in two respects. Firstly, until then only a few oppositional magazines had existed at all, but they disappeared soon. Also, periodicals as a genre were something new in the Polish drugi obieg. These newly emerging periodicals, however, could consolidate despite considerable difficulties, so that they did not have to cancel their appearance immediately after the first numbers and could remain longer, in some cases even until the end of the socialist period or beyond.

Another innovation was the thematic orientation of the periodicals. They had a self-perception as a forum for political discourses. Discussions included geopolitical issues, Poland's relationship to Europe and to its neighbours, especially to the

${ }^{2}$ J. Korek, Central and Eastern Europe from a Postcolonial Perspective, in: "Postcolonial Europe", 27.April 2009, http://www.postcolonial-europe.eu/en/essays/60--central-and-eastern-europe-froma-postcolonial-perspective, access: June 25, 2013.

${ }^{3}$ R. J. C. Young, Postcolonialism: An Historical Introduction. Blackwell 2001. 
eastern ones. The titles of the journals put this issue at the centre, as e. g. "ABC. Adriatyk, Bałtyk, Morze Czarne" or "Międzymorze" [Between the oceans]. The discourse on Poland's place in Europe has been one of the major themes in the Polish political culture at least since the beginning of the 20th century, and it has been continued even after the end of the socialist system. In the periodicals of the drugi obieg protagonists of the political opposition, i.e. intellectuals living in the country, participated in a discussion which had previously been performed mainly in exile. What is the motivation for their participation? What do the emerging magazines tell us about the constitution of the oppositional milieu in the country at a time when, at first, it looked as if martial law will destroy the achievements of Solidarność?

Although some research has been done on the journals of the drugi obieg dealing with cultural and/or literary topics such as "Puls" or "Zapis"4, the politicalsociological journals regarded in this article have not been a major research topic until now, despite the fact that they were as important and well-known as their cultural counterparts. The political drugi obieg journals are discussed here form a further voice in the drugi obieg discussion which is essential to know for a history of the drugi obieg communication structures. So, it is not so much the discussed topics themselves which are interesting here, but the position of these topics in the history of discourse. Did drugi obieg journals only present the old topics discussed elsewhere from anew? Or did they additionally prepare these topics for a new public, i.e. for the oppositional reader in Poland who wanted to get information on the ongoing discourse topics outside of Poland? Maybe the journals formed a nucleus for future democratic developments, preparing the political elite of Poland after 1989? In this sense, the idea of this article is to understand the politicalsociological drugi obieg journals as a part of preparing post-colonialism and of preparing post-colonial communication structures. This article cannot develop the idea in detail, but show some basics. It is the aim of the article to provide material which is helpful for a future detailed description of these communication structures.

\section{A SURVEY: MOST IMPORTANT POLITICAL DRUGI OBIEG PERIODICALS}

The most important and at the same time the oldest of the journals in question was “Obóz. Niezależne pismo poświęcone problemom krajów ościennych" [The

\footnotetext{
${ }^{4}$ See B. Bakuła, Stand der Untersuchungen über die Kultur und Literatur des sogenannten „zweiten polnischen Umlaufs", in: Forschungsstelle Osteuropa an der Universität Bremen (ed.): Das Andre Osteuropa von den 1960er bis zu den 1980er Jahren. Berichte zur Forschungs- und Quellenlage. Bremen 2008 (= Arbeitspapiere und Materialien, Nr. 95), p. 25-34, here p. 28-29.
} 
camp. Independent journal devoted to the problems of neighbouring countries] ${ }^{5}$. The first edition was published before the declaration of martial law, namely in September 1981, and continued to exist until 1989 and longer. A total of 19 numbers were released in Warsaw, the number of pages ranged from 81-221. From 1984 to 1988, the editors also published "Biuletyn Informacyjny "Obozu", (50 numbers with 2-10 pages) with short information about important current events and in particular human rights violations in the Soviet sphere.

In Lublin during the years 1984-1989, the organization called "Niepodległość" published eight editions of the magazine "ABC. Adriatyk, Bałtyk, Morze Czarne" with a scope of 100-150 pages. In the years 1987 and 1988 in Warsaw there appeared "Międzymorze", which was called "Pismo Sekcji Wschodniej (Wydziału Zagranicznego) PPS" from number 2/3, 1988, onwards. The publisher of "Solidarność Walcząca "Prawy Margines",, edited the journal "Europe. Pismo Instytutu Europy Wschodniej" in Katowice, Warsaw and Wrocław from 1987 to 1989.

All these magazines were intended for distribution in the entire country. There is also evidence to suggest that they were read in other Eastern Bloc countries. In some other cases, the magazines were produced in parallel editions in several languages, for example, the magazine "Zona. Nieregularne społeczno-polityczne czasopismo krajów socjalistycznych Europy środkowej", which was issued according to the editorial "in some languages" 6 or the magazine "Názory/Opinie" that existed in a Polish and a Czech edition. All magazines discussed here aimed at being primarily political-sociological magazines.

A second group consisted of magazines preferably dedicated to bilateral issues. Polish-Ukrainian themes were treated in magazines edited by the Warsaw publisher WIS from 1986 as "Dialog: (Pismo poświęcone Ukrainie i stosunkom Polsko-ukraińskim)" and "Dialogi: Biuletyn Polsko-ukraiński / Polsko-Ukraińska grupa Polityczna "Dialogi" (1987-1988) and "Sučasnist': Literatura, mystectvo, susšl'ne žyttja" and the bilingual periodical "Zustriči (Zustriczi). Czasopismo studentów i młodej inteligencji ukraińskiej w Polsce" (Warsaw 1988-1990)7. PolishLithuanian topics were treated in the periodical "Lithuania" edited in Kraków by Wydawnictwo Krzyża Nowohuckiego with a focus on religious issues.

A common feature of the above mentioned periodicals is that they mostly appeared irregularly, the personal composition of the editorial board constantly

${ }^{5}$ This survey follows Encyklopedia Solidarności (www.encyklopedia-solidarnosci.pl). All quotations from the journals cited here were drawn from the originals in the archives of the Forschungsstelle Osteuropa. My thanks go to Karina Garsztecka for her help with archival sources and to Silke Plate and Wolfgang Schlott for critical reading.

${ }^{6}$ Unfortunately, it is not indicated in which languages the paper was published. Encyklopedia Solidarności does not provide any information. There exist a Polish and a Czech version in the Forschungsstelle Osteuropa.

7 In Warsaw in 1990, another journal with the title "Zustriczi. Kwartalnik ukraiński” was published. 
changed and that in many cases, especially in the larger magazines published for a longer period, publishers and publication places also changed. Despite all these difficulties at least some of the magazines managed to consolidate. This led to a process of professionalization which sometimes is visible in the composition, e.g. when "Obóz" in the issue No. 7 for the first time added an index of authors of all previous numbers. In 1983, the editors of the magazine "Obóz" presented a résumé of their work. They had to admit though that their intention to create a regularly published bi-monthly magazine had failed due to "natural causes" which had hindered this purpose. But the editors could demonstrate that the topics raised in "Obóz" for the first time meanwhile had now been taken up in other periodicals such as "Kierunki", "CDN", "Spectator" or "Niepodległość", in every case with a different focus, which underlined the importance of the topic for the editors ${ }^{8}$.

However, the degree of difficulty to continue the work on a magazine under the conditions of conspiracy is visible in the publishing history of "Obóz": In the first three editions, the publisher information was not available at all, possibly in order to escape detection by the secret police. The issues No. 4/1982 and No. 5/1982 were published as indicated on the numbers by "Spółka Wydawnicza Przyszłość", No. 6/1982 by "Drukarnia Balysa Gajauskasa" 9 . Again, the specification for No. 7 is missing. From No. 8 onwards all following issues have been published by "Wydawnictwo CDN" in cooperation with "CDN Press Fund London", which changed its name from No. 10/1085 onwards to "Pulse Publications". In number 17/1990 still "Wydawnictwo CDN" appeared as publisher, but it was given the address of the former Warsaw editorial member Andrzej Ananicz ${ }^{10}$ as correspondence address before 1990 this was nearly impossible in drugi obieg publications.

Just as, for example, in the case of the literary journal "Zapis"11, there existed also authors or members of the editorial staff in the political and sociological periodicals. They published both in journals such as "Obóz" or "ABC" as well as in official periodicals. Andrzej Ananicz is a good example of how many editors and

8 “Obóz” December 1983, nr 7, p. 1.

${ }^{9}$ In 1978, Balys Gajauskas was sentenced to 10 years in a camp because of his work at the Lithuanian oppositional journal "Aušra" and of his collection of materials of the anti-Soviet Lithuanian Partisan movement of the years 1944-1952. Gajauskas was a member of the Lithuanian Helsinki committee which has been founded on November 25, 1976 (so in Kronika obozu: Litwa. In: "Obóz" 1981, nr 1, p. 74). This demonstrates that there was a good relationship between obóz and the Lithuanian oppositional movement.

10 Andrzej Ananicz, born 1951, from 1981 in the editorship of "Obóz" 1982/83 lecturer in the USA, after his return he worked in "Obóz". See Beata Losson: Andrzej Ananicz. In: Encyklopedia Solidarności.

${ }^{11}$ See J. Bocheński, $O$ "Zapisie". Zaczęto się od sześciu egzemplarzy. In: Bibuła. Wolne stowo w Polsce 1976-1980. Dodatek do "Rzeczpospolitej", czerwiec 2003; L. Szaruga, "Zapis". Wstęp do opisu. In: Piśmiennictwo - systemy kontroli - obiegi alternatywne. Ed. J. Kostecki. A. Brodzka. Warszawa 1992, p. 297-319. 
staff members constantly shifted between opposition and official structures without any problems ${ }^{12}$. Ananicz had been a research assistant at the University of Warsaw since 1974. He signed the protest call against the amendments to the Constitution in 1976. In the late 1970s he worked with "Nowa"13, an underground publisher, and engaged since September 1980 in the structures of Solidarność structures. He was a founding member of the editorial board of "Obóz". In 1982 and 1983, he held a teaching position at Indiana University in Bloomington, USA, and immediately after returning to Poland he continued his underground activity in "Obóz", since 1985 even as editor in chief. Since the 1970s Ananicz could pursue his career both in the official sphere as well as in the opposition milieu. He could postpone the one in favor of the other, even if the activity in "Obóz" had to be kept secret. This is a telling case on the discourse structure in Poland of those years: there existed a variety of communication connections between the official sphere and drugi obieg. There was no strict separation between the discourse spheres. Thus, the oppositional journals did not influence their "own" group, but also the official readers of the "other" group.

\section{THE AMBIVALENT RELATIONSHIP WITH THE WEST: COMMUNISM AND SCIENTIFIC RESEARCH}

A prevalent idea of the times was that the intellectuals of the oppositional scenes in the entire Soviet bloc had fallen behind the Western standards of scientific considerations regarding their own sociological, political and historical conditions. The editors of "ABC" noted a "shocking primitiveness" at the field of visional thinking in the whole intelligentsia of the Eastern Bloc countries and made the structure of state socialism responsible for that:

In a certain way 40 , in the USSR 60 years have reached their goal ${ }^{14}$.

From this, the editors developed the legitimacy of their journal:

The more useful is every statement to [...] geopolitics (even if this word may sound a bit bad), every attempt to start a dialogue on this topic ${ }^{15}$.

Thus, the journals of the opposition were intended as a counter-reaction against official conformist thinking. The editors of the periodicals wanted to catch up with Western discourse standards. The editors and authors therefore to a great

\footnotetext{
12 Vgl. B. Losson, A. Ananicz. In: Encyklopedia Solidarności.

13 See J. Jankowska et al., Ludzie Nowej 1977-2007. Warszawa 2007, p. 141.

14 N. N., Poglady. In: “ABC” 1984, nr 1, p. 7.

${ }^{15}$ Ibidem, p. 19.
} 
extent considered themselves actors in a decentralized process of modernisation according to Western patterns. This is most evident in the fact that from time to time - verbatim or slightly modified - contributions from well-known Western authors on key issues were reprinted in oppositional journals. The examples are, in particular, the essays of Hannah Arendt on totalitarianism theory ${ }^{16}$. Considering the fact that even today this theory plays a central role in intellectual discourses in Central and Eastern Europe ${ }^{17}$, although it is regarded as outdated in the countries of the former West, one can imagine how great an influence the underground periodicals had on the political and sociological discourses also after the end of state socialism.

The culmination of the ideal of scientific standards was the plan to create an East European Institute ("Instytut Europy Wschodniej") according to the Western model. In the introduction to No. 7 of "Obóz" with the subtitle of "Instytut Europy Wschodniej", the planned establishment of this institution was presented. The authors placed themselves in the tradition of Western European research, namely of the German "Institutes for Research on the East", ("Institute für Ostforschung") or the institutions of "Sovietology", and "in particular the Anglo-Saxon school ${ }^{18}$." The editors of "Obóz" also edited a book series which was at the same time conceived as a publication organ of the Institute. The idea behind it was that if not the realization of a parallel society as a whole, then at least there should be a parallel knowledge-based society, a virtual community of intellectuals. ${ }^{19}$ Bearing

\footnotetext{
${ }^{16}$ H. Arendt, Rewolucja wegierska a imperializm totalitarny, in: “Europa” 1988, nr 2(4), p. 4-46. At the beginning, information on the first publication in English, the existence of a German translation and the name of the translator into Polish were given, including a demonstration of the intention of scientific approach in formal details.

17 See L. Rensmann, Totalitarismus. In: Politische Theorie. 22 umkämpfte Begriffe zur Einführung. Hrsg. Gerhard Göhler u. a. Wiesbaden 2004; Czas totalitaryzmu. Stalinizm, faszyzm, nazizm i pokrewne systemy polityczne w XX wieku. Ed. J. Szymoniczek, E. Król. Warszawa 2011; D. Trutkowski, Wohin treibt die Totalitarismusforschung? Möglichkeiten und Grenzen eines Analysemodells moderner Diktaturen. In: Diktaturüberwindung in Europa. Ed. B. Hofmann u.a. Heidelberg 2010, p. 258-274.

18 Wstęp. In: "Obóz" 1983, nr 7. There were at least three issues of the announced Seria Sowietologiczna (all present in the archives of Forschungsstelle Osteuropa, Bremen): 1. Dzieje kościota grecko-katolickiego na Ukrainie po II wojnie światowej / Hans-Dieter Komp; [unauthorized translation from German]. “Powiew” Instytutu Europy Wschodniej. - 1985; 2. Dzieje Kościoła grekokokatolickiego na Ukrainie od 1944 r. / Hans-Dieter Komp ; translation. [from German] commissioned by the editorship of "Obóz" ; ed. Fr. Luszczyński. Prepared for print by Instytut Europy Wschodniej. - Reprint from: Polska Oficyna Wydawnicza "Powiew", Warszawa 1985. - 1986; 3. Śmierć Lenina. Walka o władzę [a talk led by G. Urban with Borys Bażanow] / B. Bażanow, G. Urban; translation from English prepared for print by Instytut Europy Wschodniej; ed. T. Lubicz - 1984.

19 Directly after the implementation of martial law the creation of an underground state (państwo podziemne) was postulated. In 1982, Zbigniew Bujak proposed in a letter to Władysław Frasyniuk the creation of institutions such as a Council of Culture (Rada Naukowa), a Council for National Education (Rada Edukacji Narodowej), a Council for Polish Science (Rada Nauki Polskiej) and a fund
} 
all this mind, the authors continued the tradition of the Flying Universities of the $1970 \mathrm{~s}^{20}$.

Dealing with what editors and publishers called communism research, i.e. analyses of developments in the real existing state socialist societies and their relationship to the underlying doctrine, took a large space in the periodicals. Again, in many cases, works of researchers from Western countries or émigrés constituted the centre of attention ${ }^{21}$. The Communist Studies should not only be of strongly scientific character and present state of the art research, but should also have a supranational character. In the first issue of the magazine "Obóz" from 1981 the editors explained their intention in starting the publication of the journal as follows:

Guided by the belief that the current and future fate of Poland is closely connected with the emerging changes in the Communist world, we have decided to create a magazine that is devoted to the problems of the societies within this system. Our goal is to familiarise especially the Polish readers with the participants and leaders of the democratic oppositions in various communist countries, but also with the history, traditions and culture of their nations ${ }^{22}$.

This was what the proposed communism research should be based on. The views of the leading protagonists of the underground movements of various socialist countries were compiled in the magazines. The 10th issue of the journal "Obóz" of 1985 was devoted to the "expansion of communism", which the editors understood as the efforts of the Soviet Union to increase its influence in the regions of the world. The issue comprised articles dealing with the situation in Asia, Africa and America, but not with the situation in Europe. This was followed by another bloc of articles devoted to the internal affairs of the Soviet Union. As the editorial members stated above, this arrangement was also aimed at demonstrating the contrast between the outer expansion and the inner hollowness of the Soviet Union ${ }^{23}$.

Research on communism for the editors of "Obóz" did not only imply catching up with Western standards. Issue $8 / 1984$, which was devoted to the relations between "the West and the USSR" was supposed to demonstrate the "often existing

for Polish grants („,kasy stypendialne”) which had to form a part of an underground network of intellectuals. Marek Kunicki-Goldfinger points out that the effectiveness of these institutions is often exaggerated by historians. See M. Kunicki-Goldfinger, Społeczny Komitet Nauki. In: Solidarność podziemna 1981-1989. Ed. A. Friszke. Warszawa 2006, p. 549-620, esp. p. 556-558. Nevertheless, the Społeczny Komitet Nauki had a direct influence on the drugi obieg journals. E.g. the editors of Europa thanked for the financial help obtained from them (See "Europa" 1988, nr 2(4), p. 2).

${ }^{20}$ See R. Terlecki, Uniwersytet Latający i Towarzystwo Kursów Naukowych 1977-1981. Ed. Instytut Europejskich Studiów Społecznych. Kraków-Rzeszów 2000.

${ }^{21}$ E.g. the reprint of a chapter of Ludmila Alekseeva "Istoria inakomyslia" on the Lithuanian opposition in "ABC" 1986, nr 3, p. 19-36.

22 Od redakcji. In: “Obóz" 1981, nr 1.

23 Od redakcji. In: “Obóz” 1985, nr 10, p. 3 
misunderstandings of communism in the western world24." Critical remarks were addressed especially to the supporters of the peace movement in the Western world "whose followers do not seem to notice that the advocates of similar ideas in Eastern Europe are charged with the loss of freedom for their convictions ${ }^{25}$." This shows a typical ambivalence: on the one hand, the editors represented the ideal of a scientifically-oriented approach following the example of Western intellectuals and research institutions. On the other hand, they opposed heavily many of the views expressed in the West, especially the attitude towards "communism", that is, to the real impact of the political system of the Soviet Union on every-day life. The editors and authors claimed to have a more precise knowledge and therefore also, to some extent, a greater legitimacy than the desk researchers of the West who analyzed the phenomena from a safe distance.

This was also visible in the classifications of global politics. Thus, the character of communism research was not limited to the neighbouring countries but also led to a global perspective in which the world events were seen in the light of the EastWest conflict. In 1985, "Obóz" published a special issue on "the directions of expansion" in which it looked at the continents of Asia, Africa and America in terms of the rivalry between the two superpowers. The tight anti-communism of the magazine is expressed in the editorial introduction in which the editors complained about the fact that the U.S. is "doing everything they can to lose the race [for the influence in the world], point by point ${ }^{26}$." When perestroika came into view, the editors of "Obóz" emphasized that we should wait and see before joining in the "fanfare of 'perestroika' and 'glasnost'". They stressed that, after all, "the gulag is not yet full27."

\section{THE DISCOURSE ON THE LOCALIZATION OF POLAND IN EUROPE}

The graphic design of the title page of the oldest magazine "Obóz" illustrates which area of Europe the editors wanted to cover in their journal: The caption "Obóz" is placed in front of a map of Eastern Europe in such a way that the diacritical mark of the o kreskowane refers to a space that essentially includes the satellite states of the Soviet Union, including the Baltic Soviet republics and the Soviet Republics of Belarus and Ukraine ${ }^{28}$. This space forms the camp ("Obóz"), and so

\footnotetext{
${ }^{24}$ Wprowadzenie. In: “Obóz” 1984, nr 8, p. 4.

${ }^{25}$ Ibidem.

26 Od redakcji. In: “Obóz” 1985, nr 10, p. 3, op. cit.

27 Od redakcji. In: “Obóz” 1988, nr 14.

28 "Obóz" 1982, nr 3 gives a detailed visualisation of this "camp". It includes the Baltic states, Ukraine, Belarus, Romania, Bulgaria, Yugoslavia, Hungary, and the CSSR. The GDR is indicated as
} 
the title of the journal gives the association to a prison camp, which is fully permissible. Attention is thus made to the fact that the installation of this camp was forced by Moscow. The basic idea of the magazine was then to look for structures of a political order for these countries beyond the pattern of Moscow's socialism, but based on a diametrically different foundation with the consequence to exclude the Soviet Union. However, simultaneously a separation from the "West" was intended.

The magazine "ABC" also provides a graphical design of their idea of Central Europe on its front page. Here, already the newspaper subtitle "Adriatyk, Bałtyk, Morze Czarne" indicates the main topic. The journal "Międzymorze" on the title page eliminated any boundaries in its visualization of the area. However, it did present the land mass ",between the seas [międzymorze]” Baltic Sea and the Black Sea showing the rivers Vistula, Nemunas, Pripyat and Dniepr.

Issue 11 (1987) of "Obóz" devoted a special number to the topic of Central Europe (Europa środkowa). In the first section entitled "Central Europe" basic texts of Milan Kundera, István Bibó and Kazimierz Bielski were printed. This was followed by two texts dealing with Poland / Czechoslovakia and Hungary / Romania. The third block presented texts on the geopolitical possibilities of realization of the sovereignty of the nations in Central Europe. Here, already the "perspective of a possible fall of the Soviet empire" (p. 4) was assumed, as was said already in the editorial.

At first glance, the connection of the discourse on Central Europe with the topics of the opposition movements is not apparent. As the editors point out in the editorial, the idea is to present basic localisations. This seems to have nothing to do with the major concerns of the opposition movement, i.e. the struggle for the liberation from Soviet rule and from the state socialist system of society. However, the connection is that the editorial raises the question of whether some important events and manifestos of the opposition may serve as a founding base of a future Central Europe which was yet to be created. They mentioned here the "sławne posłanie Solidarności" 29 from 1981, Charter 77 and the Hungarian democratic opposition from the year $1984^{30}$.

In a programmatic article in "Międzymorze", which the editors wanted to be explicitly understood as a statement of their own view, the authors mentioned the other existing magazines that covered similar concepts. According to the authors, "Obóz", the oldest one, despite its announcement about the "neighboring countries"

\footnotetext{
a part of reunited Germany. In the East a state named "Państwo Moskiewskie" is situated, an allusion to the term "Muscovy" used for the middle-Age period of Russian history.

${ }^{29}$ Compare S. Gerhardt, Polska Polityka Wschodnia. Die Außenpolitik der polnischen Regierung von 1989 bis 2004 gegenüber den östlichen Nachbarstaaten Polens (Russland, Litauen, Weißrussland, Ukraine). Marburg 2007, p. 68.

30 Wstęp. In: “Obóz” 1987, nr 11, p. 4.
} 
dealt with the entire Communist bloc. The journal "Nowa Koalicja", the authors continued, was more anti-Russian than anti-Soviet and therefore limited its attention to the territories of European Russia. The authors claimed that the magazine "ABC" is especially informative, but rather as a type of a lexicon than a scientific journal ${ }^{31}$.

"Międzymorze" show how the old concept of early modern Rzeczpospolita Obojga Narodów should be applied to modernity in a new way by Józef Piłsudski ${ }^{32}$. The programmatic introduction to the first edition of the magazine ${ }^{33}$ gives as its first goal once more the common struggle against the Soviet occupation and gives examples of cooperation in the past, such as the merger of Piłsudski and Petlura or the "coexistence of Poles and Lithuanians in a single state for centuries". An unambiguous reference to the Republic of the Two Nations was the formulation of the intention to take over from that State all that which was good, namely the coexistence of several nations and religious tolerance. This new edition of the Jagiellonian idea of Poland was not limited to "Międzymorze". In number 5, the "ABC" magazine also presented ${ }^{34}$ and discussed the federal ideas of Piłsudski ${ }^{35}$.

This is a variation of the Central European theme, as it has occurred in many forms in the countries between Germany and Russia since the end of the 19th Century again and again. Since its beginning, the discussion on Central Europe has constantly focused on a set of key questions that are always asked. They differ slightly depending on the national standpoint.

These are:

- the definition of the term "Central Europe". The typically given arguments are cultural locations (religious affiliation) and historical developments since the Middle Ages

- the problem of the position between German Reich and Russia / the Soviet Union

- the question of supranational political structures in this space.

The views expressed in the periodicals thus turn out to be a part of a discourse that is considerably older than state socialism. Already at the turn of the 20th century and especially in the interwar period, concepts of the so-called Third Way were discussed not only in Poland ${ }^{36}$ but also in other countries of Eastern Europe.

31 Łukaszów, Międzymorze. In: “Międzymorze”, 1988, nr 2-3 (3-4), p. 28-29.

32 The term and idea of Międzymorze go back to Józef Piłsudski. See P. Okulewicz, Koncepcja "międzymorza" w myśli i praktyce politycznej obozu Józefa Pitsudskiego w latach 1918-1926 (The Concept of Międzymorze in the Political Thought and Practice of Józef Pitsudski's Camp in the Years 1918-1926). Poznan 2001.

33 "Międzymorze" 1987, nr 1, p. 1-2.

${ }^{34}$ J. Łojek: Idea federacyjna Józefa Piłsudskiego. In: “ABC" 1987, nr 5, p. 13-23; W. Bukowiński, Idea jagiellońska. In: “ABC" 1987, nr 5, p. 24-29, op. cit.

35 Ibidem.

${ }^{36}$ See Polske wizje Europy w XIX i XX wieku. Ed. P. O. Loew. Wrocław 2004. 
They were taken up again after the Second World War, especially in the writings of authors such as Milan Kundera, Jenő Szúcs and others ${ }^{37}$. Seen in the context of an intellectual history, the magazines considered here are located in the tradition of the Central European debate by referring and transferring the key messages to the Polish situation of the 1980s.

The discourse on the future shape of Poland has always been inseparably linked to the discourse of this concept, which, in turn, automatically raises the question of the relations between Poland and its neighbours, and particularly with its neighbours to the east ${ }^{38}$. The idea of Central Europe was not new, and neither were the ideas expressed in the underground magazines. They presented topics form anew that were formulated much earlier. In order to understand the position of the underground magazines, it is necessary to shortly trace the history of this discourse.

Immediately after the war, when the westward shift of Poland was implemented, in Paris and London exile circles started lively and controversial discussions on the evaluation of the newly created territorial situation. The majority of emigrants demanded the restoration of the borders of the Treaty of Riga and thus a revision of the newly created political order in the area between Warsaw and Moscow.

The major places of this discourse were the exile journals "Kultura" in Paris and "Wiadomości" in London. The London exile remained on their position"39, but in the Paris exile soon there took place certain developments, especially in the circle of Jerzy Giedroyc, the editor of the magazine "Kultura"40. "Kultura" was not only a forum for Polish but also Lithuanian, Ukrainian and Belarusian exile authors to offer their viewpoints. This corresponded to the view of Giedroyc who claimed it necessary to come into contact with the intellectuals from these countries in order to develop a basis of political ideas about the future. Giedroyc found an important supporter in Czesław Miłosz who, after the end of his diplomatic activity for the Polish state, turned into one of the most important and most prom-

${ }^{37}$ See Ch. Domnitz, Europäische Vorstellungswelten im Ostblock. Eine Topologie von Europanarrationen im Staatssozialismus. In: Europa im Ostblock. Vorstellungen und Diskurse (1945-1991). Ed. J. M. Faraldo, P. Gulińska-Jurgiel / Christian Domnitz, p. 61-82. On the history of the idea of Europe in the Polish culture from 1795 to 1945 see W. Borodziej, B. Brzostok, M. Górny, Polnische Europa-Pläne des 19. und 20. Jahrhunderts. In: Option Europa. Deutsche, polnische und ungarische Europapläne des 19. und 20. Jahrhunderts, vol 1: Essays. Ed. W. Borodziej et al. Göttingen 2005, p. 43-134.

${ }^{38}$ For further information: M. Boruta, Wolni z wolnymi, równi z równymi. Polska i Polacy o niepodległości wschodnich sąsiadów Rzeczypospolitej. Kraków 2002.

${ }^{39}$ See R. Habielski, Die Pariser Kultura und das unnachgiebige London. In: Die polnische Emigration und Europa 1945-1990. Eine Bilanz des politischen Denkens und der Literatur Polens im Exil. Ed. Ł. Gałecki, B. Kerski. Osnabrück 2000, p. 59-72.

40 On Kultura and its role in this discussion see J. Pomianowski, Die Pariser Kultura und die Vision einer neuen polnischen Ostpolitik. In: Die polnische Emigration und Europa 1945-1990. Eine Bilanz des politischen Denkens und der Literatur Polens im Exil, op. cit., p. 105-112. 
inent advocates of direct communication with the Eastern neighbours of Poland 41 . Both Giedroyc and Miłosz were personally affected by this subject because their families came from the areas in which an overlapping of Polish, Lithuanian and Belarusian cultural influences had always taken place. So they evolved the idea of a culture symbiosis which both in their journalistic, literary and political actions they intensively propagated despite such unfavorable conditions, e.g. after the end of World War II.

In this way, "Kultura" became a place of intellectual maturation resulting in articles such as "Polska 'Ostpolitik'" by Juliusz Mieroszewski42. Recognizably influenced by the current events of the West German-Polish rapprochement, Mieroszewski formulated a similar intent of Poland in terms of its closest eastern neighbours. He clearly explained the necessity of abandoning the former Polish eastern territories including the so-symbol-laden cities of Vilnius and Lviv with the aim of a post-socialist world order to enable a good neighbourhood of future democratic nations in Eastern Europe. However, expressing these views in the 1970s seemed to be completely utopian.

With the beginning of independent Polish underground publishing activities there appeared voices which went further with more general topics and not only limited themselves to the problems of every-day-struggle, e.g. the writings of Michnik, Holzer, Zagajewski, and Tischner. However, it was only the underground magazines which presented the topic in all its breadth and made it public in opposition circles. The texts of the participants in the discourse of the 1950s, especially the texts of Juliusz Mieroszewski, were reprinted. The editors added further articles which adapted the theories from the 1950s to the current situation. Here lies the importance of the underground magazines. They acted as transmission belts of a discourse hitherto mainly from the exile into the land and in wide circles of Polish society, a discourse about the future position of Poland in Europe and Poland's relation to its neighbours.

With the reception and dissemination of the ideas of the exile discourse, the role of the underground magazines, however, was not finished. Rather, the editor groups now developed into a kind of think tanks of the opposition, in which concepts for the future were discussed. They already had a vision of a future in which Poland would design its own foreign policy without the control from Moscow. The visionary width often found in the texts demonstrates that in the texts the actors thoroughly prepared themselves and their public for the day which would bring a reorganization of Europe after the end of state socialism.

${ }^{41}$ See M. Kornat, Między literatura a polityka. Korespondencja Jerzego Giedrojcia z Czestawem Miłoszem (1952-2000). In: J. Giedroyc, Czesław Miłosz, Listy 1952-1963. Ed. M. Kornat. Warszawa 2008, p. 5-68.

42 J. Mieroszewski, Polska "Ostpolitik". In: "Kultura" 1973, nr 6 (309). On Mieroszewski see R. Habielski, Realizm, wizje i sny romantyków. O pisarstwie Juliusza Mieroszewskiego. In: J. Mieroszewski, Finat klasycznej Europy. Ed. R. Habielski. Lublin 1997, p. 330-340. 


\section{LITERATURE AND POLITICS}

It is noteworthy that the editors felt compelled to reprint such basic texts as Polska "Ostpolitik" or Rossyjski kompleks Polski of Mieroszewski. Apparently, the level of awareness of these texts in the country was small. This goes to show that the repeatedly claimed good accessibility of exile literature, such as the issues of the Paris "Kultura", in fact, had a limited effect in the country.

Interesting and revealing is the observation that the issues raised in the underground magazines topics were not formulated in the country for the first time. They were not previously formulated in the field of politics but in and by means of literature. Thus, there was a lively discussion about the former Polish eastern territories and the relationship of Poland to Lithuania, Belarus and Ukraine in literary journals. Soon after the Second World War, a nostalgic memory literature emerged $^{43}$, and again and again the Eastern theme was taken up in literature ${ }^{44}$. The cinema also took up the subject though in different forms.

Nevertheless the discussions in the underground magazines provided something fundamentally new. Instead of treating the subject only as a "sideshow", namely using the field of literature as a means to discuss political issues, the authors were now playing open cards and openly formulated confrontational concepts that had previously been hidden and only tangible in the literary texts. Discourses, which had been previously performed under the protection of literary fiction were now made openly, such as the still burning problem of the necessity of renunciation of Vilnius and Lviv. This issue had been previously addressed only in the form of nostalgic memoirs, but the pros and cons were discussed openly.

It seems as if the political function of literature was not regarded or ignored consciously. In the sphere of political debates it was clearly not possible to act on a sensitive issue such as the loss of Vilnius, but with literary means these issues could be performed very well. It is quite obvious that the need for public discussion of this complex could be sublimated for a long time using literature. The reception of the works by Czesław Miłosz provides Revealing evidence for it. Already in his early work "The Captive Mind" from 1953 he had treated the problem of the Baltic States in a separate chapter. He also discusses the issue of the PolishLithuanian relationships in "Valley of the Issa". Miłosz's works can be regarded in Poland as well known, even before his visit in 1980. Nevertheless, it is remarkable that he played no role in the political debate about the relationship of Poland to its neighbours, which was started in the underground magazines. In none of the men-

${ }^{43}$ See W. Schlott, Kindheitsparadies und Inferno. Die östlichen Grenzlandgebiete im Spiegel der polnischen Nachkriegsprosa. In: “Osteuropa” 1990, nr 7, S. 659-671.

${ }^{44}$ See Kresy w literaturze. Twórcy dwudziestowieczni. Ed. E. Czaplejewicz, E. Kasperski. Warszawa 1996. 
tioned magazines did Miłosz appear, nor were there any texts or reference made to him - a harsh contrast to the reverence and esteem which Miłosz enjoyed in the underground press. The reason for this may be the fact that Miłosz was regarded as a literate and not as a political writer, which went hand in hand with the way Miłosz perceived himself.

The editors of the underground magazines felt this opposition between literature and political journalism. It can be exemplified with the following. When "Obóz" published a bloc of texts on "culture" in issue 12/1987, the editors legitimized this, on the one hand with the important role that culture had as a field of suppression of the state, and as a possible "hope" of the opposition on the other hand. This idea was not new but for the editors it seemed to be a kind of revolution to present texts on "culture" in their journal which was politically - sociologically oriented ${ }^{45}$.

\section{ZA NASZĄ I WASZĄ WOLNOŚĆ - OR ONLY ZA NASZĄ?}

In all the ideas on Central Europe which were discussed in the magazines, a strong tendency to favour federal concepts in favour of conceptions of a national order is obvious ${ }^{46}$. The idea of a federation takes up a large part in the thinking of most authors presented here. Problems of the federal thinking were neglected. Supporters of federal ideas did not want to see that it had often been border disputes or conflicts with populations in border areas which had in the past prevented both good neighbourly relations and mergers.

In the fall of 1980, there began a discussion of the expected and hoped processes of disintegration of the Soviet empire in "Biuletyn Dolnośląski"47. It included typical passages with speculations about future developments in the Eastern Bloc $^{48}$. The author who published under the pseudonym "Optimist" was not only convinced of the need, but also of the possibility of such federations: "Let us remember that peoples [narody], which have a lot in common (e.g. significant minorities on both sides of the border), are condemned to a common existence" 49 . According to this author, "the era of nation-states at the end of the 20th century belonged to the past" 50 . The author suggested a reorganization of Eastern Europe

\footnotetext{
${ }^{45}$ Od Redakcji. In: “Obóz” 1987, nr 12, p. 4.

${ }^{46}$ Federal ideas play an important role in Polish political thinking regardless of political views, see K. Grygajtis, Polskie idee federacyjne i ich realizacja w XIX i XX wieku. Częstochowa 2001.

47 “Optymista”: Konfederacja pięciu federacji, März 1981. In: “Obóz” 1981, nr 3, p. 85. See Polska w Europie. In: “Biuletyn Dolnośląski”, Oktober 1980, p. 36-35.

48 Ibidem, p. 86.

${ }^{49} \mathrm{Ibidem}, \mathrm{p} .87$.

50 Ibidem, p. 85 .
} 
in form of a "confederation of five federations", namely a "Czech-Polish-Slovak", a Hungarian-Rumanian, a Yugoslav (with the possible inclusion of Bulgaria), and - after the collapse of the Soviet Union - another Baltic Federation, possibly with Finland, and finally a Belarusian-Ukrainian ${ }^{51}$.

The authors of contributions to federal ideas had the intention to think not only for the interests of Poland, but also for the interests of the peoples and countries of the whole area. There evolved a conflict as due to their view of themselves as activists not only for their own interests but also for the others, the Polish thinkers were convinced of the sincerity of their intentions. However, this very view just prevented them from seeing the effect of their positions in the eyes of the others. In particular, they did not recognize the fact that the others sometimes never approved of the arguments put forward by their Polish colleagues in good faith.

The Polish dealing with the neighbours to the east, i.e. Lithuania, Ukraine and Belarus was the acid test for the Polish ability to abstract from their own points of view. Polish thinkers knew about this problem. Juliusz Mieroszewski wrote: "If we call for simplifying the area which includes Ukraine, Lithuania and Belarus, with the letters ULB, then we have to admit that the ULB area in the past and, consequently today, is something more than a bone of contention between Poland and Russia. The ULB area determinates the shape of Polish-Russian relations which either show Polish imperialism or Poland as a satellite state" 52 .

The practice of summarizing the territory of the states of Ukraine, Lithuania and Belarus under the term ULB is conceivable only on the basis of Polish culture. Here again, this practice has a long tradition because it repeats the idea of the Polish kresy - a term of Polish Romantics which remained critical in Polish thinking about the region east of the Bug river deep into the 20th century. However, for the residents of these areas this concept did not only fail to function as a selfdescription, but they rejected it as an oktroi from Poland.

The problem can be exemplified by the slogan Za nasza $i$ wasza wolność. It was renewed in Poland in the 1980s in the course of the discussion about a new deal with the Eastern neighbours ${ }^{53}$. In the November Uprising of 1830/31, when the slogan was created, it was used to symbolise the idea of the common struggle of Polish and Russian intelligentsia against the oppression of government authority. The slogan then served to the corresponding part of the Russian intelligentsia to awaken sympathy and solidarity, and it should do so now. In doing so, intelligentsia members could rely on the fact that the Russian opposition in the Soviet Union since 1968 had used this slogan as a slogan of the opposition. Also, during the ini-

${ }^{51}$ Ibidem, p. 87.

52 J. Mieroszewski, Rosyjski kompleks Polski i obszar ULB. In: “ABC” 1984, nr 1, p. 22.

${ }_{53}$ Compare: K. M., Za naszą i wasza wolność, za nasze i wasze trwanie. In: “Biuletyn Dolnośląski”, Oktober 1980, p. 25-27. 
tial phase of Solidarność and during the period of their legal existence, their leaders had repeatedly sought contact with members of the Russian opposition and had called with leaflets for the unionisation of Russian workers following the Polish Solidarność model.

The alliance with the Russian opposition implied a latent attack on the "small nations" in between, though Polish oppositional members were not always aware of it. Only with some delay did they understand that it was necessary to first start the discussion with the direct neighbours and only then with the Russian opposition movement. However, there were also voices for the interests of their neighbours which moderated the enthusiasm for the federalist ideas:

The comments of our Ukrainian colleagues in terms of the federation concepts seem to be of highest importance. Sometimes, these concepts are regarded as a request for the creation of supranational organizations that threaten the idea of an independent Ukrainian state. We note that the Polish experience with federalism was different and think that if we are looking for ways for Polish-Ukrainian cooperation today, more distance to the concepts of the past is essential ${ }^{54}$.

Special attention was devoted to the Lithuanians, Belarusians and Ukrainians who lived on the territory of the People's Republic of Poland. The writers of the oppositional magazines recognized that their problem was not russification but polonization, either "in full awareness of the state power, or often subconsciously by ourselves". The editors made attempts to gain the confidence of the minorities in the Polish culture and proposed a "union of the peoples in the area from the Baltic to the Black Sea". The word "sojusz" and not "federacja" was used for the term of "union" as "federacja" was used by Piłsudski for the idea. Nevertheless, it is striking that there was almost no differences between Piłsudski's idea and the idea of the authors of "Międzymorze" - which is not surprising because the magazine was then a publishing organ of the Eastern Section of the PPS, similarly to Piłsudski's Party. It is likely that the avoidance of this influential term was an offer to Poland's eastern neighbours which would make them feel safe.

\section{THE SHOCK OF THE DIRECT ENCOUNTER AFTER 1989}

It was a shock, therefore, when representatives of the Polish intelligentsia finally, after the opening of the borders, had to realize how high was the resentment of the eastern neighbours towards Poland. In number 17/1989 of the magazine "Obóz" an interview with an anonymous Polish informant was published. He drew a picture of the intense Lithuanian reservations against Poland and ques-

\footnotetext{
${ }^{54}$ Nie jesteśmy ukraińskim Piemontem. In: “ABC”, 1986, nr 4, p. 9.
} 
tioned the previously repeatedly theme of solidarity of the Lithuanian and Polish Catholic churches. He drew such a strong enemy image of Poland that the interviewer asked whether it is the opinion of the Lithuanians or maybe Moscow. However, Poland was a greater threat to the Lithuanian national independence. ${ }^{55}$

In the next number, however, a replica of a journalist from "Kurier Wileński" not only proved the existence of several factual errors and even ignorance of the interviewee, but also condemned his views ${ }^{56}$. This interview and the replica are a clear indication that the time before 1989 had obviously not been used for a differentiated elaboration of the view of the Polish-Lithuanian relations.

The way in which the Polish intelligentsia had dealt with the problem of Lithuania is exemplified in a contribution by Zygmunt Komorowski about "Saint Casimir and the Polish-Lithuanian relations" 57 . He listed a number of saints that connect Poland with other countries, including Saint Kazimierz who had a Polish "Piast" name but was "Lithuanian by blood"58. With this argument the author wished to underline the similarity of the Polish and Lithuanian cultures before asking why the Lithuanians separated themselves. In response to this question the main conflict issues between the two peoples arising were mentioned: the processes of polonization in the past, the seizure of Vilna by Żeligowski, and even events from the Middle Ages such as the victory of the Poles over the Lithuanian tribe of the Jaćwęgi. However, there was no discussion of these topics.

Merely mentioning the key challenges was already an important step in the Polish-Lithuanian discourse because before that the Polish intelligentsia mainly behaved as if all this had not taken place. But even now attempts were made to relativize: the author noted that the processes of polonization had had a voluntary character and was not forced by any sort of authorities, so that the accusation of polonization was absurd. According to the author, atrocities were committed by both sides, which for him was a means to calm down the problem. "Although we, Poland, have been rather less brutal and more elegant (we would say "intelligent"), the Polish debt is still [...] great."

This is a significant step towards the opposite side, but one thing was missing at this time, namely the response from the other side. Obviously, the absence of such posts in the magazines of the Polish showed that underground magazines did not serve as a forum for the Polish-Lithuanian exchange before 1989. This stands in sharp contrast with the exile where the exchange took place in magazines like "Kultura" already in the 1950s. This does not mean that there had been no

55 Obecny stan stosunków polsko-litewskich to krótkowzroczność. Rozmowa z K. Tołłoczko. In: “Obóz” 1990, nr 17, p. 131-140, here p. 136.

56 J. Tryk, Do autora wywiadu „Obecny stan stosunków polsko-litewskich”. In: “Obóz” 1990, nr 19, p. 87-92.

57 Z. Komorowski, Św. Kazimierz a stosunki polsko-litewskie. In: ABC" 1986, nr 3, p. 9-19.

58 Ibidem, here p. 9. 
Polish-Lithuanian contacts at all. The Lithuanian Sajüdis movement was formed with the help and modelled on the Solidarność organisation ${ }^{59}$. Various other contacts existed, but in most cases these contacts were limited to individual contacts and they did not find any representation in the oppositional media such as the drugi obieg journals. The bilateral Polish-Lithuanian treatment of mutual problems started only after 1989, but in a very intensive way. However, it was the Polish underground magazines which had provided the basis for an understanding position against the neighbours in much of the Polish intelligentsia in the country.

\section{CONCLUSION}

The journals taken into consideration here were a medium of transmission. They presented basic ideas and problems of political thinking to the drugi obieg public in the country by adapting or reprinting crucial texts. Thus, they actively prepared the Polish public for their future role in a democratic state, without knowing when this future would start. It could be the task of further studies on continuity and changes of Polish elite before and after 1989 to demonstrate that many of the editorship members or article writers belonged to the elite of the Poland after 1989, thus prepared democracy by the use of the journals as a field of experiment ${ }^{60}$.

Moreover, the journals acted as a transmission medium: They "translated" topics from the field of literature into politics. This was a delicate task. In literature, it was possible to put a nostalgic view on the lost Eastern areas, but it was impossible to speak about this topic outside the limits of literature and arts for a long time. When journals like "Obóz" and "ABC" ignored this unspoken taboo, they got resentments and harsh critics form their readers. But this was the beginning of the real discussion process, and not the nostalgic view of the earlier literary articles. So, even if the journals do not present anything new and do not have the position of the most up-to-date forum for Polish political conceptions, their meaning for the implementation of the democratic process in Poland is considerable. In this sense, the journals prepared the postcolonial situation of Poland after 1989.

${ }^{59}$ See Sajūdis - Solidarność: strateginès partnerystès pradžia / Solidarność - Sajūdis: początek strategicznego partnerstwa. Ed. Instytut Historii Polskiej Akademii Nauk, Lietuvos istorijos institutas. Warszawa 2010.

${ }^{60}$ See e.g. E. Wnuk-Lipiński, Demokratyczna rekonstrukcja. Z socjologii radykalnej zmiany społecznej. Warszawa 1996, chapter “Elity" p. 111-234. 
